\title{
The Role of Muscle Cells and Fat Cells in Nerve Regeneration Evaluated by in vivo Electric Conductivity
}

\author{
ANAMARIA VICTORIA BUMBU1*, MARCEL PERIAN², RADU FECHETE ${ }^{3}$, CALINA DAN ${ }^{4}$, IOANA RADU5, KLARA BRINZANIUC 6 \\ 'Emergency County Hospital Oradea, Plastic Surgery Department, 37 Republicii Blvd., 410167, Oradea, Romania, \\ 2Univeristy of Medicine and Pharmacy Targu. Mures, Depatment of Physiology, 38 Gh. Marinescu Str., 540139, Targu Mures, \\ Romania \\ ${ }^{3}$ Technical University of Cluj-Napoca, 15 C. Daicoviciu Str., 400020, Cluj Napoca, Romania \\ ${ }^{4}$ Univeristy of Medicine and Pharmacy Targu. Mures, $38 \mathrm{Gh}$. Marinescu Str., 540139,Targu Mures, Romania \\ EUniversity of Medicine and Pharmacy of Targu Mures, $38 \mathrm{Gh}$. Marinescu Str.,540139, Targu Mures, Romania \\ 6Univeristy of Medicine and Pharmacy Targu Mures, Department of Anamatomy and Embryology, 38 Gh. Marinescu, 540139, \\ Targu Mures, Romania
}

\begin{abstract}
Peripheral nerve reconstruction is a much debated subject nowadays that is why new surgical techniques are being performed. It has been demonstrated that after a complete section of a peripheral nerve, the healing process takes time, and most frequently the recovery is not complete. Muscle cells and fatcells due to their chemical components, can contribute in the healing process of the peripheral nerves. The purpose of this study is to evaluate the effect of wrapping a muscle flap or an adipose flap around the primary suture of a cuted nerve in order to improve the motor nerve regeneration in a rat model by using in vivo electric conductivity measurements.
\end{abstract}

Keywords: fat cells, muscle cells, nerve regeneration, in vivo electric conductivity

In plastic surgery one of the most challenging pathology is peripheral nerve injury. New surgical techniques are being developed and the old ones are being improved, because the functional recovery after nerve reconstruction is often incomplete [1, 2]. Peripheral nerve injuries may occur due to stretching, compressions (carpal tunnel syndrome), cut or damaged in accidents (sport injury or car crash). Several studies showed that if a complete nerve transection occurs, even if the surgeryis perfectly adequate, full nerve recovery should not be expected $[1,3,4]$. There are several techniques that can improve the nerve functional and morphological recovery. One of these procedures is to wrap the site of the suture with a variety of substances, such as fat, muscle, vein [5-8]. Another technique is to use nerve conduits (autogenous biological conduits, nonautogenous, and nonabsorbable conduits), to protect the new scar formation, heaving the role of a nerve wrap [9-12]. Nerve conduits are useful when there is a nerve defect bigger than $5 \mathrm{~cm}$. Muscle cells have in their componence stem cells which are round, minimally adherent cells and have the property to contract spontaneously [13-16]. This muscle derived stem cells have a promising role in regenerative medicine. Since peripheral nerve injuries are most of the times associated with severe traumas, this cells can provide a unique advantage for the restoration of damaged tissues [13]. On the other hand, autogenous fat grafts consisting in whole adipose tissue have also a number of benefits. One of them is that they are rich in adipose stem cells even if they are not isolated. These adipose stem cells have a great therapeutic potential because of their trophic factor secretion and differentiation potential [17-24].

Several studies, using different methods, such as MRI (magnetic resonance imaging), and histologic analysis have demonstrated from the structural point of view that using nerve wraps (muscle cells and adipose cells) after primary repair can decrease scar tissue formation [9 - 11, 25]. The purpose of our study is to investigate, from the

*email: bumbuanamaria@gmail.com, Phone: +40742266006, functional point of view, using in vivo electric conductivity measurements how the fat cells and muscle cells help the nerve regeneration process. We assume that the use of these two types of cells would enhance motor nerve recovery in this study.

\section{Experimental part}

The Ethics Committee of The University of Medicine and Pharmacy of Targu Mures approved the experiment and study protocols, according to document $323 / 2017$. In this study we have used twenty-four adult Wistar Albino rats that were divided in three equal groups. Nerve transection and repair procedure was performed under general anesthesia with ketamine/xylazine ( $75 \mathrm{mg} / 5 \mathrm{mg} / \mathrm{kg}$ i.m). For all animals the left sciatic nerve was transectioned using a No. 11 blade and reconstructed under magnification loupes (2.5X Keeler). In all groups direct suture was performed using 8.0 Prolene sutures. For the first group the primary suture was performed without w rapping the nerve (fig. 1a), for group number two the reconstructed site was wrapped in a local muscle flap (fig. 1b), and the third group was wrapped in adipose flap harvested from the interscapular region of the same rat (fig. 1c). The right

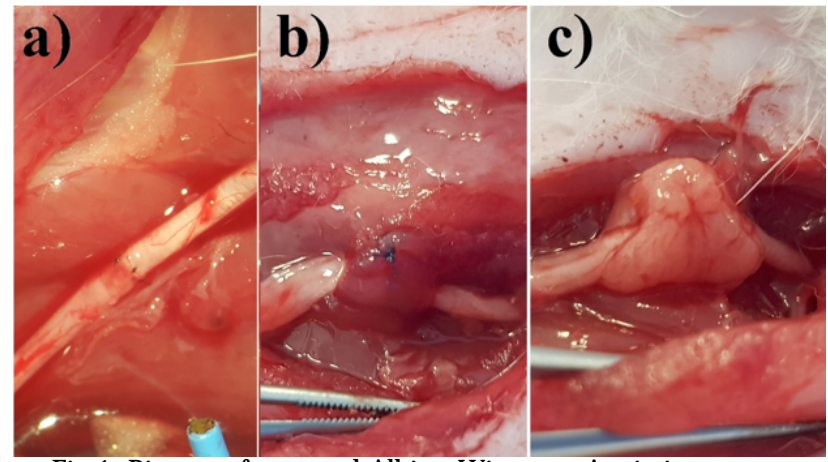

Fig 1. Picture of exposed Albino Wistar rats' sciatic nerve reconstruction after injury for a) the first group with direct suture; b) $2^{\text {nd }}$ group with muscle flap wrapping the suture and c) $3^{\text {rd. group }}$ with adipose flap wrapping the suture 
sciatic nerves were used as control group. At 4, 6, 8 and 10 weeks in vivo electric measurements were performed for all rats.

For the electrical stimulation of the sciatic nerve, we developed an external programmable pulse generator based on the PIC16F877 microcontroller (Microchip. Inc. Arizona USA) which is capable to generate stimuli in a range of 0.2 to $6 \mathrm{~ms}$ (milliseconds) width. The stimulation frequency can be set from $60 \mathrm{ppm}$ (pulses per minute) to $8000 \mathrm{ppm}$ and the amplitude can be varied continuously from 0 to $24 \mathrm{~V}$. The firmware was written in Pic Basic Pro a compiled with Proton Basic software (Crownhill Associates Limited, UK). The schematic of the logic unit can be seen in figure 2 . To prevent any unwanted electric discharge, the device is operated from a battery pack of $6 \mathrm{Li}$-Ion accumulators, $4.2 \mathrm{~V}$ each, when fully charged. The device is permanently monitoring the charge status of the battery pack and warns user if the capacity drops below $1 / 3$ of the full charge value. Ten stimulation protocols can be stored in the device's EEPROM area and recalled using the rotary switch when the stimulator is operating in memory recall mode.

The stimulus was delivered to the nerve in bipolar mode, using two parallel silver wires, $0.7 \mathrm{~mm}$ diameter spaced at $5 \mathrm{~mm}$. The tip of the stimulating electrodes was bent, in order to avoid any damage of the stimulated nerve. The negative stimulating electrode was placed in distal position ant the positive electrode was in proximal position. Any electrical contact between stimulation electrodes and surrounding tissue was avoided.

The acquisition of the compound muscle action potential (CMAP) was performed using 3 electrodes, two signal electrodes and one electrode for active ground. The acquisition electrodes were 2 silver needles spaced at $5 \mathrm{~mm}$ and inserted into the gastrocnemian muscle. A third electrode, served as active ground, was placed distally on the hind paw (fig. 3). CMAP potentials were amplified using an AD620 instrumentation amplifier (Analog Devices, Norwood, Massachusetts, USA). To avoid any significant input impedance, we used an LMC6484 quadruple CMOS operational amplifier with unity gain as buffer in the front of the AD620 amplifier. This configuration has input impedance in the range of $10 \mathrm{T \&}$ !, making any tissue impedance imbalance insignificant. The third operational amplifier (IC1C) of the LMC6484 chip is used as active ground driver, as shown in figure 4.

For the signal acquisition we used a $\mathrm{PCl}-4452$ acquisition card (National Instruments, Austin, TX, USA) connected to a standard P4 pc. The signals were measured, filtered and stored using LabVIEW software. Filters were configured as following: high pass filter cut-of frequency $10 \mathrm{~Hz}$, low-pass filter cut-of frequency $10 \mathrm{kHz}$, and a $50 \mathrm{~Hz}$ notch filter ON. The sampling rate was set at $22 \mathrm{kHz}$. An image of the recorded signals is represented in figure 5 . As it can be seen in figure 5 , the conduction time was measured from the beginning (raising front) of the stimulus to the first spike of the muscle potential. In our protocol, stimulation width was $0.5 \mathrm{~ms}$ and stimulation frequency was $1 \mathrm{ppm}$.

\section{Results and discussions}

The average values of response voltage, response time and response velocity are presented in figure 6 , figure 7 and figure 8 for all groups (direct suture, muscle flap

$\begin{array}{lc}\text { EXT.PACEMAKER Ver.2 } & \text { YO6PIR-2015 } \\ \text { Generator de impulsuri cu perioada si latime variabila }\end{array}$
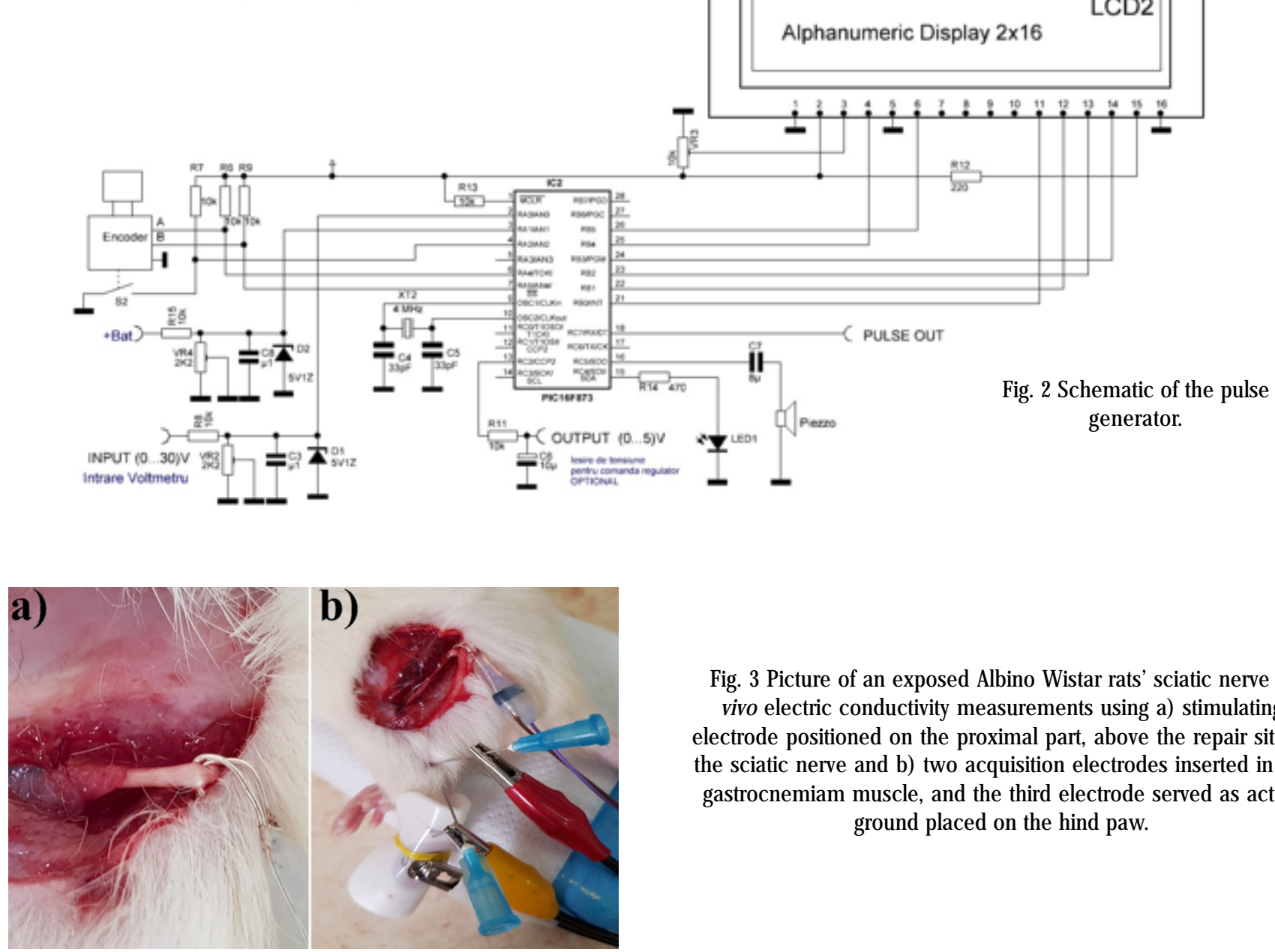

Fig. 3 Picture of an exposed Albino Wistar rats' sciatic nerve in vivo electric conductivity measurements using a) stimulating electrode positioned on the proximal part, above the repair site of the sciatic nerve and b) two acquisition electrodes inserted in the gastrocnemiam muscle, and the third electrode served as active ground placed on the hind paw. 

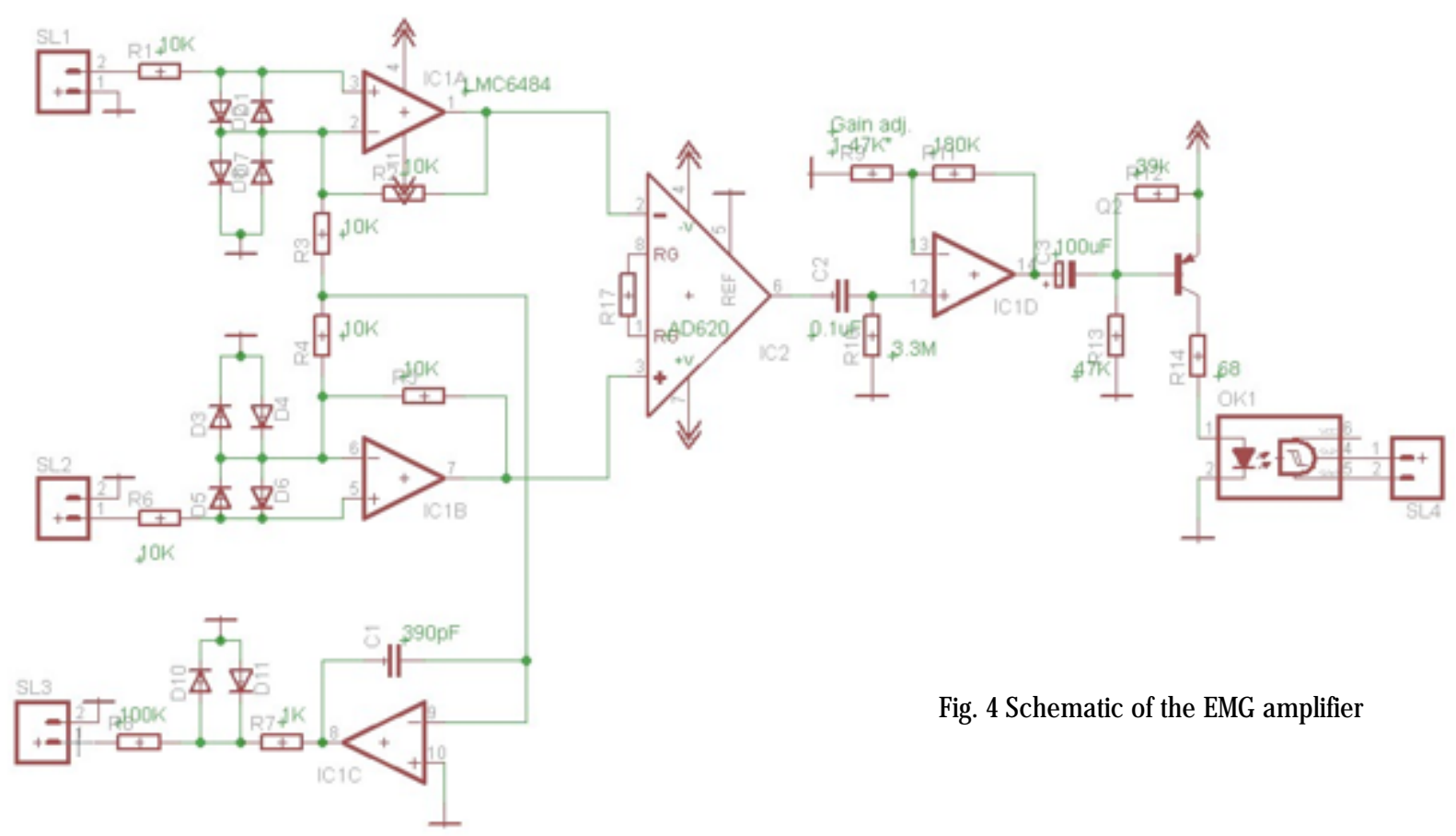

Fig. 4 Schematic of the EMG amplifier

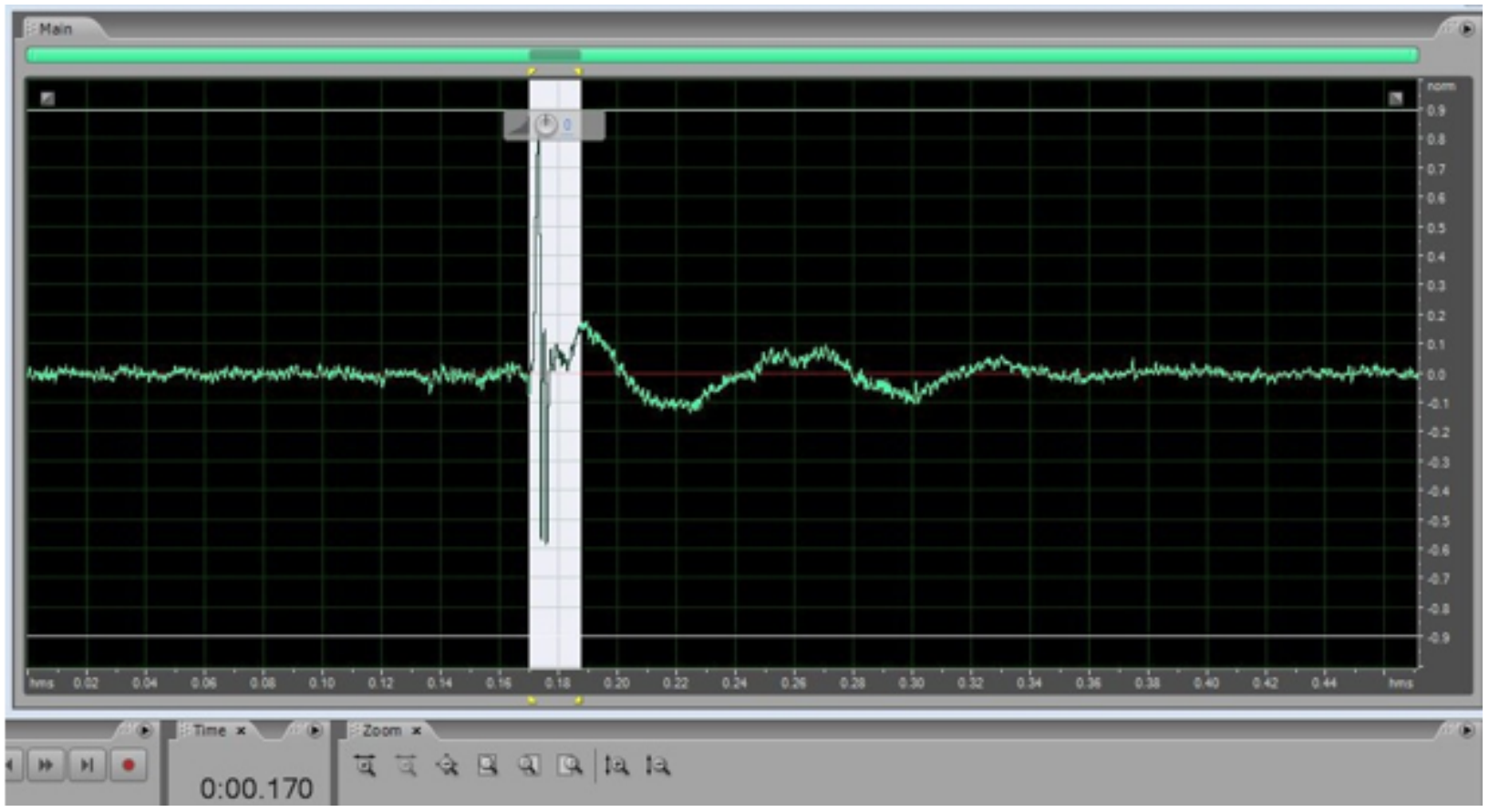

Fig. 5 Recorded CMAP (compound muscle action potential) and measurement

wrapping and adipose flap wrapping). In each case, the parameters measured for the healthy nerve (blue square) are compared with those measured for injured sciatic nerve (magenta circle). We can observe that in all groups there are significant differentiations between the healthy nerve's average voltage (2.8-4 V group one figure 6a; 3-5 V group two figure 7a and 4-4.7 V group three fig. 8a) and under recovery sciatic nerve (4-6 V group one figure 6a; 4.7-7.8 $\mathrm{V}$ group two figure $7 \mathrm{a}$ and $5.7-7.7 \mathrm{~V}$ group three fig. 8a). The higher average voltage response is seen in the
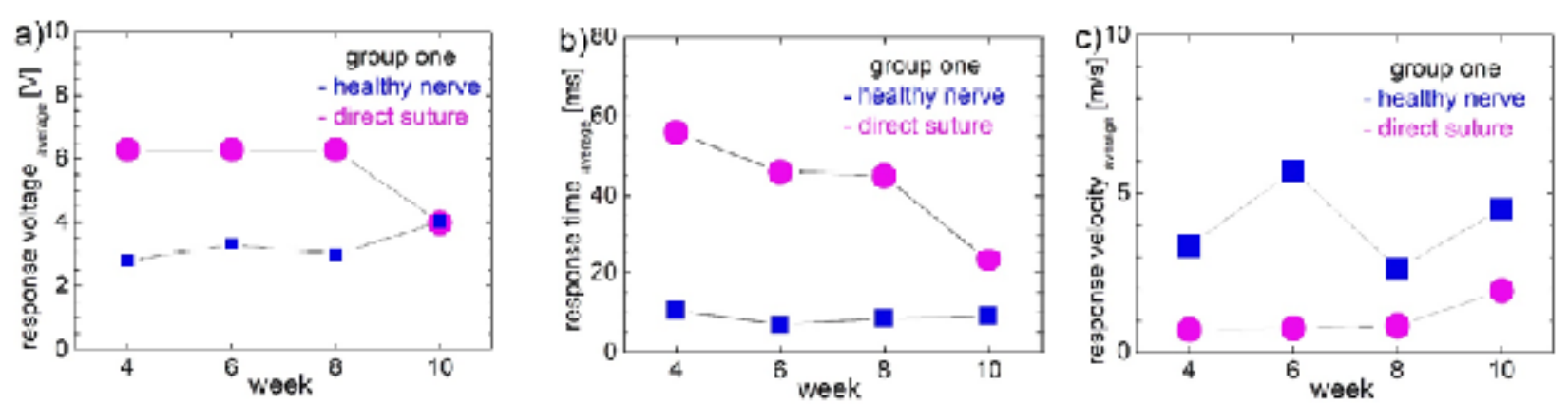

Fig. 6 In vivo electric conductivity parameters compared for healthy nerve and direct suture. The measured parameters were the average voltage response a), the time response $b$ ), and the velocity response $c$ ). 

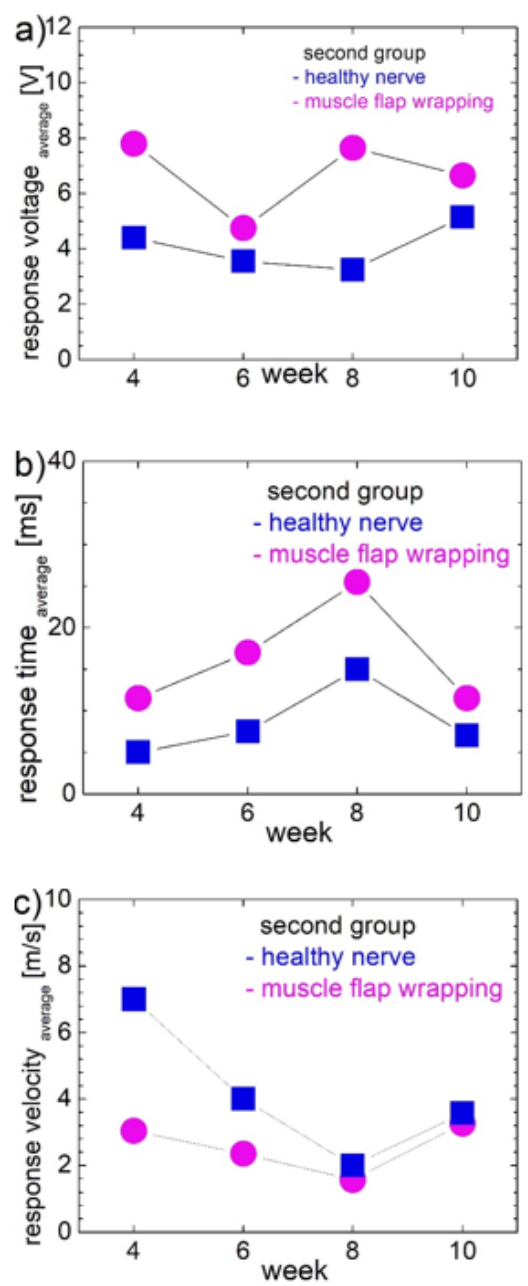

adipose flap wrapping group, and the smallest response is seen in the direct suture group.

The average time response is presented in figure $6 \mathrm{~b}, 7 \mathrm{~b}$ and $8 \mathrm{~b}$. The healthy nerve's behavior is similar in all three groups heaving measurements between 5-15 ms, while the injured and repaired nerve has big differences between all reconstruction procedures. The average time response for the direct suture group is much higher (23-56 ms, fig. $6 b)$ than in group number two where the time response is between 11 and $17 \mathrm{~ms}$ (fig. 7b). Also the adipose flap wrapped group has higher response time (5-27 ms. fig 8b) than the muscle flap wrapped group.

The average response velocity is represented in figures $6 c, 7 c$, and $8 c$. In the healthy nerves we observe a fluctuation between the values, but the interval between week 8 and 10 is characterized by increasing average response velocity values measured in all groups. The average velocity response is higher in the case of muscle flap wrapped group 1.00-3.26 m/s (fig. 7c), than in the direct suture group 0.71-1.92 m/s (fig. $6 \mathrm{c}$ ), and larger than the average velocity response values measured for the third group 1-5 m/s (fig. 8c). The conduction velocity increased progressively from 4 to 10 weeks in the first (direct suture) and second (muscle flap wrapped) group, compared to the third group (adipose flap wrapped) where it decreased. We can observe that the response time in the injured nerve in the second and third group is increasing excepting the interval between the 8 and 10 week. In this period of time in the muscle flap wrapped group the values decrease (heaving the same behavior like the healthy nerve), while in the adipose flap wrapped group it increases. The average response time for the second group is longer than the other two groups.
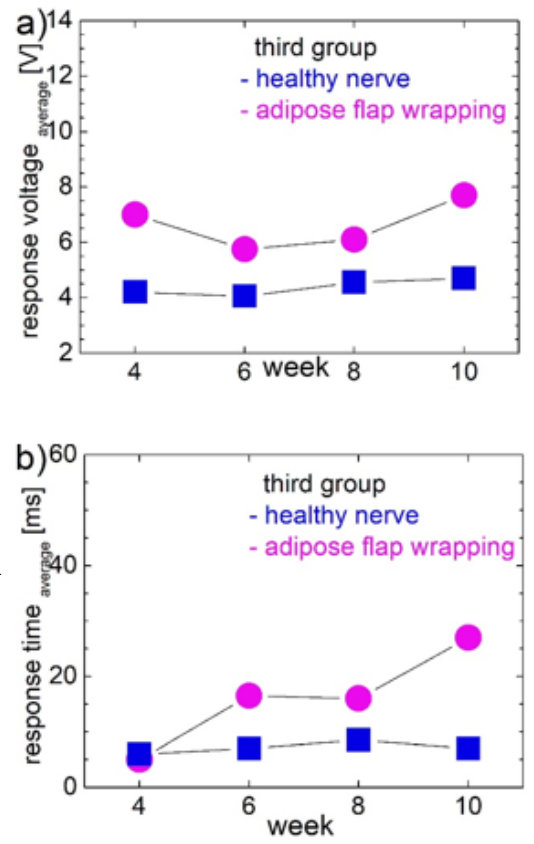

Fig. 8 In vivo electric conductivity parameters compared for the group of Albinos Wistar rats with healthy sciatic nerve and direct suture with adipose flap wrapping. The measured parameters were the average voltage response a), the time response $b)$, and the velocity response $\mathrm{c}$ ).

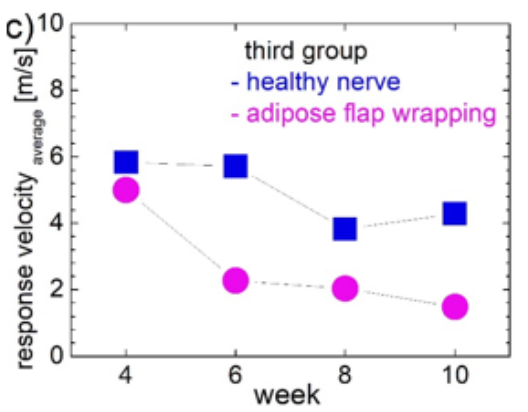

The response voltage is an important parameter and we can see for the first group that the values between the healthy and injured nerve become almost the same, demonstrating that from the average voltage response point of view the nerve in healed after 10 weeks [25]. From the response velocity values point of view, the rats' sciatic nerve is not healed, but in the first and second group the values become closer to the healthy nerve values, in comparison with the third group where the values are decreasing.

We can consider that until the 8 week the recovery of the peripheral nerve is not restored, but after this period of time the healing process passes over the lesion and the functionality of the nerve is faster restored [25].

\section{Conclusions}

In vivo electric conductivity is a technique that can be used to evaluate the peripheral nerve healing process from the functional point of view. Significant functional differences were observed between the direct sutured group and the other two groups. From the average voltage response point of view, the rat's sciatic nerve from the first group is healed at 10 weeks after injury and repaiered using direct suture. From the average response velocity one can say that the muscle cells wrapped around injury have a bigger role in regeneration than the fat cells. Overall, the electric conductivity measurements showed that the functionality of an injured sciatic nerve is restored faster using muscle cells and direct suture, compared to adipose cells wrapped around injured site. 


\section{References}

1.J O0-YUP LEE, THOMAS J. PARISI, PATRICIA F. FRIEDRICH, ALLEN T. BISHOP AND ALEXANDER Y. SHIN, Does the adition of a nerve w rap to a motor nerve repair affect motor outcomes?, Wiley Periodicald, $p$. 562-567

2.ALLAN CH. Hand Clin;16, 2000, p. 67-72

3.MURATORI L, RONCHI G, RAIMONDO S, GIACOBINI-ROBECCHI MG, FORNARO M, GEUNA S., Microsurgery, 32, 2012; p. 383-387

4.FOX IK, BRENNER MJ, JOHNSON PJ, HUNTER DA, MACKINNON SE. Microsurgery, 32, 2012, p. 552-562.

5.XU J, VARITIMIDIS SE, FISHER KJ, TOMAINO MM, SOTEREANOSDG., J Hand Surg Am, 25, 2000, p.:93-103.

6.J ONES NF, SHAW WW, KATZ RG, ANGELES L., J Hand Surg Am, 22, 1997, p. 527-535.

7.LINDSEY JT, BRYAN WW, ROBINSON JB JR, ORENSTEIN HH. J Reconstr Microsurg, 12, 1996, p. 475-478.

8.MEEK MF, COERT JH, NICOLAI JP. Plast Reconstr Surg, 107, 2001, p.:622-623.

9.MATHIEU L, ADAM C, LEGAGNEUX J, BRUNEVAL P, MASMEJEAN E. Chir Main, 31, 2012, p. 311-317.

10.KIM PD, HAYES A, AMIN F, AKELINA Y, HAYSAP, ROSENWASSER MP., Microsurgery, 30, 2010, p. 392-396.

11.KIM SS, SOHN SK, LEE KY, LEE MJ, ROH MS, KIM CH., J Hand Surg Eur, 35, 2010, p. 214-219.

12.SUCIU, B.A., HÃLMACIU, I.,BUD V., COPOTOIU, C., FODOR, D., TRAMBITAS, C., GODJA, D., VUNVULEA, V., MOLNAR, C., BRÎNZANIUC, K., Mat Plast, 54, no. 4, 2017, p. 626-628

13.*** Muscle-derived stem cells in peripheral nerve regeneration: reality or illusion?
14.TAMAKI T, OKADA Y, UCHIYAMA Y et al. Stem Cells. 25(9), 2007, p. 2283-2290.

15.BEANE OS, FONSECA VC, COOPER LL, KOREN G, DARLING EM. PLOS ONE 9(12), 2014, e115963.

16.TAMAKI T, UCHIYAMA Y, HIRATA M et al. Front. Physiol. 6, 2015, p. 165.

17.FRANCES M. WALOCKO, ROGER K. KHOURI JT., MELANIE G. URBANCHEK, BENJ AMIN LEVI AND PAUL S. CEDERNA., Microsurgery, 36 (1), 2016.

18.LOPATINAT, KALININA N, KARAGYAUR M, STAMBOLSKY D, RUBINA K, REVISCHIN A, PAVLOVA G, PARFYONOVA Y, TKACHUK V., PloS One, 6, 2011, el7899.

19.MARCONI S, CASTIGLIONE G, TURANO E, BISSOLOTTI G, ANGIARI S, FARINAZZO A, CONSTANTIN G, BEDOGNI G, BEDOGNI A, BONETTI B., Tissue Eng A, 18, 2012, p. 1264-1272.

20.ZUK PA., Mol Biol Cell, 21, 2010, p. 1783-1787.

21.YANG J , ZHANG H, ZHAO L, CHEN Y, LIU H, ZHANG T., Cell Biochem Funct, 30, 2012, p. 505-514.

22.LEE ST, CHU K, JUNG KH, IM WS, PARK JE, LIM HC, WON CH, SHIN SH, LEE SK, KIM M, ROH JK., Ann Neurol, 66, 2009, p. 671-681.

23.RAZAVI S, RAZAVI MR, ZARKESH ESFAHANI H, KAZEMI M, MOSTAFAVI FS., Dev Growth Differ, 55, 2013, p. 648-655.

24.REID AI, SUN M, WIBERG M., Neuroscience, 199, 2011, p. 515-522. 25.BUMBU A.V., FECHETE R., PERIAN M., BUMBU B.S., KLARA BRINZANIUC., Acta Medica Marisiensis, 64(1), 2018, p. 22-27.

Manuscript received: 8. 01.2019 